\title{
7 \\ Upliftment of Agriculture labour through Labour Laws
}

Dr. Ashfaque Alam, Associate Professor, Dept. of Management, Jharkhand Rai University, Ranchi.email: ashfaque.alam@jru.edu.in; ashfaq2321@gmail.com

\section{Abstract}

India after 73 years of independence, the conditions of agricultural labourers are still pathetic, they are one of the most exploited and downtrodden classes in our social rural hierarchy. They are living unsecured and underprivileged life which is full of uncertainties. In India agricultural labourers fall in the category of unorganized sector, with uncertain seasonal income with no social security protection. The another big reason is that, agriculture in India still depends upon the intensity of monsoon.

Despite of many attempts taken by the government in the past to improve the socio-economic conditions of the agricultural labourers across the country still they are the worst sufferers in the society efforts seems to fail because it has consisted of short-term solutions unrelated to the general pace and direction of the economy as a whole. This paper seek to examine the problems of agricultural labour and steps taken by government to meet the situation.

Keywords: Upliftment of Agriculture labour, Farm labour, Labour Laws

\section{Introduction}

The Indian economy is largely dependent on agriculture and even after 70 years after the independence the livelihood of the Indian farmer depends on the grace of monsoon. Good monsoon is essential to better harvest and bumper productions. Seventy per cent of our population is directly or indirectly engaged in agricultural activities in India while around 58 per cent of the total employment in our country is through agriculture sector. In India the agricultural sector contributes around 18 percent of the GDP.

A major portion of the agriculture space lacks manual irrigation systems and utterly addicted to monsoon rains. The frail monsoon rains results into failure of crop production that affects the economy in an exceedingly negative manner that affects different areas too. Traditional monsoon rains keep a check on food inflation but, in an exceedingly state of affairs of drought, costs soar considerably, affects life et al and therefore the country could even import. 


\section{(C) Dr. Ashfaque Alam}

Notably, the failure of monsoon includes a giant impact on the lifetime of the Indian farmer and farm labours. Failure or deficient precipitation is one in all the large reason behind the farmer's suicides in mass across the country.

Not only the agriculture sector, however, monsoon conjointly affects other sectors as several sectors depend upon monsoon, either directly or indirectly. Therefore monsoon plays an enormous role in India, the agricultural output of rain-fed crop areas within the country has social, political, similarly as economic implications. Whereas on the opposite hand, agriculture labour is counted within the class of unorganized sector in our country, therefore their financial gain is not fastened. For this reason they are living an unsafe and underprivileged life and earning around Rs. 160 per day along with full uncertainty. They (agricultural labourers) are one of the most exploited classes in the rural hierarchy. They are a unit one in all the foremost exploited categories within the rural hierarchy.

\section{Problems of Agriculture Labour:}

\section{Traditional Indian Farming}

Indian farming has always been labour intensive in contrast to the massive mechanised farming of the USA and different countries. Traditionally Indian farmers have depends on old cultivation techniques, organic fertilizers and pesticides, as well as seeds that's quality has been improved using natural selection methods as opposed to genetic manipulation.

\section{Employment}

The agricultural labourers have to face the problems of unemployment and underemployment. A large number of days (of the year), they have to remain unemployed because of the lack of work on the farms while alternative sources of employment also not exist.

\section{Income}

The wages and family incomes of agricultural workers are very low in our country. After the initiation of the Green Revolution, wage rates started increasing however, as prices also increased considerably, the wage rates did not increase in the same proportion. Presently labours are getting around Rs. 150 to 200 per day under the MGNREGA in rural areas. 
(C) Dr. Ashfaque Alam

However, the minimum wage in Bihar, effective from April 2018, is Rs 237, Rs 210 in Jharkhand and Rs 326 in Haryana.

\section{Low Wages for women}

Generally women agricultural workers are forced to work harder and paid less in comparison to male workers.

\section{Indebtedness}

In the absence of proper banking system in the rural areas and trial process of sanction by the commercial banks, farmers prefers to take loans from moneylenders, landlords at a very high rate of interest which (interest rates) traps them into debt.

\section{Rise in migration of Labours}

Though, the Green Revolution significantly increased remunerative wage employment opportunities in the assured irrigation areas while nearly stagnated in the vast rain-fed areas or in those areas where agriculture depends upon monsoon.

\section{Initiatives taken by the Government}

\section{Minimum Wages Act :}

The Minimum Wages Act was passed as long back as in 1948 and from that point forward the need of applying it to farming has been continually felt. Means the Act is not pertinent to farming division.

\section{Eradication of Bonded Labour:}

Since Independence, endeavours have been made to nullify the insidiousness of reinforced work since it is exploitative, barbaric and violative of all standards of social equity. In the section on Fundamental Rights in the Constitution of India, it has been expressed that exchanging people and constraining them to do begging is restricted and can be punished under the law.

\section{Provision for accommodation:}

Laws have been passed in many states for giving accommodations to the farmworkers. The ceiling of landholding serves this purpose. The Bhoodan movement is also one of the methods by which those who 
have land, contribute voluntarily to landless people. Another method is co-operative farming, the landless people can improve their lot only through acquiring land.

\section{Employment Guarantee Scheme}

Rural Employment (CSRE), National Rural Employment Jawahar Gram Samridhi Yojana (JGSY) and National Food for Work Program (NFFWP), Mahatma Gandhi Rural Employment Guarantee Act MGNREGA

\section{Special organizations for development}

Small Farmers Development Agency (SFDA) and Marginal Farmers and Agricultural Labourers Development Agency (MFAL) were formed in 1970-71 to take care of the issues of farm works of the nation.

The Government has passed the Unorganised Workers' Social Security Act, 2008 to provide social security benefits to the workers including agricultural labourers within the unorganised sectors.

This Act specifies formulation of suitable welfare schemes for unorganised workers on matters relating to: (i) life and disability cover, (ii) health and maternity benefits, (iii) old age protection and (iv) any other benefit as may be determined by the Central Government through the National Social Security Board. Various Schemes, formed by the Government to provide social security cover to the unorganized workers, which include agricultural labourers are listed in the Schedule I of the above Act are as under:

\section{A. Indira Gandhi National Old Age Pension Scheme}

B. National Family Benefit Scheme

C. Janani Suraksha Yojana

D. Handloom Weavers' Comprehensive Welfare Scheme

E. Handicraft Artisans' Comprehensive Welfare Scheme

F. Pension to Master Craft Persons

G. National Scheme for Welfare of Fishermen and Training and Extension 
(C) Dr. Ashfaque Alam

\section{H. Aam Admi Bima Yojana}

I. Rashtriya Swasthya Bima Yojana (Ministry of Health and Family Welfare).

Besides these, Pradhan Mantri Jeevan Jyoti Bima Yojana, Pradhan Mantri Suraksha Bima Yojana and Atal Pension Yojana were launched by the Government to provide social security coverage to farm labourers.

\section{Findings}

Agricultural labourers form the lowest rung of the socio-economic ladder in the country and their condition is worse than that of the unorganised labourers in other sectors. They are affected by unique problems which are associated with the agricultural sector like seasonal employment, irregular employment, underemployment, disguised unemployment, and in some cases, even the landowners small and marginal farmers - turning into wage labourers.

Moreover, they also face other problems like low wage payment, payment in kind, gender disparity in wages, etc. The Government has brought in many legislative measures to improve the socio-economic conditions of the agricultural labourers over the years, but in many States, these have not been implemented since agriculture comes under the control of the State Governments. Also, many measures which are available to the industrial workers are not available or applied to the agricultural labourers.

\section{Conclusion}

To succeed, the farm labour policy has to be an integral part of the overall policy for economic development. The basic solution has to lie in increasing demand for rural labour through intensive agriculture and through larger non-farm employment. This programme for the longer term can then be supported by other short-term programmes aimed at assuring, meanwhile, a more reasonable minimum wage to farmers, food and clothing at more reasonable prices through well-organised marketing societies, and off-season employment opportunities for earning supplementary income.

\section{References}




\section{(C) Dr. Ashfaque Alam}

Moshe, Y., Sachs, (1963), "World mark Encyclopaedia of the Nations", United Nations, New York, pp. $112-118$.

https://shodhganga.inflibnet.ac.in/bitstream/10603/40323/6/chapter-4.pdf

https://www.skymetweather.com/content/agriculture-and-economy/dependency-of-indian-agriculture-onmonsoon/

https://cjp.org.in/rights-of-farmers-agricultural-labourers-and-forest-workers-in-india/

https://pib.gov.in/newsite/PrintRelease.aspx?relid=155354 